How to implement the narrative approach in different phases of a positive psychological research? A four-dimensional analysis

Salmela, Mari

University of Lapland, Finland (msalmela@ulapland.fi)

Uusiautti, Satu $\bowtie$

University of Lapland, Finland (Satu.Uusiautti@ulapland.fi)

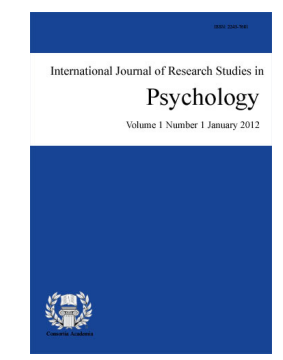

ISSN: $2243-7681$ Online ISSN: 2243-769X

OPEN ACCESS

\title{
Abstract
}

This article discusses the nature and core of narrative research by reflecting on the various elements of the narrative research approach in an example study that focused on high-achieving Finnish graduates' study paths in a positive psychological study. The dimensions of the narrative research approach analyzed in this article were (1) the narrative approach in the meta-theoretical basis of the research; (2) the narrative approach in data collection; (3) the narrative approach in data analyses; and (4) the narrative approach in the reliability evaluation of the research.

Keywords: narrative research; narrative inquiry; analysis of narratives; narrative analysis; reflexivity; positive psychology 


\section{How to implement the narrative approach in different phases of a positive psychological research? A four-dimensional analysis}

\section{Introduction}

Narrative research represents a qualitative research approach in which the focus is on narratives as the transmitters and constructors of knowledge (see, e.g., Bruner, 1986; Carter, 1993; Clandinin \& Rosiek, 2007; Connelly \& Clandinin, 1990; Pinnegar \& Daynes, 2007; Spector-Mersel, 2010). However, it is not a consistent theoretical-methodological trend, but merely a loose methodological framework or fragmented field of research related to narratives (Heikkinen, 2002a). Only the concept of narrative is quite widely used in everyday life and in science and therefore, it is understood differently in various contexts (Gergen \& Gergen, 2011; Squire et al., 2014).

Conceptions on the nature of narratives (psychological vs. social explanations of narrative) within the narrative paradigm as well as opinions on whether narrative research is interested in the structure or process of the narrative, human experiences, or rhetoric figures of speech and conventions create tensions between narrative researchers (Gergen \& Gergen, 2011). According to Gergen and Gergen (2011), a relational constructionist perspective in the narrative paradigm smooths over controversy and specifies the various ways of conducting narrative research.

Spector-Mersel (2010) specifies that the narrative paradigm has six dimensions: it can analyze the ontology, epistemology, and methodology, as well as the purpose of narrative research and the positions of the researcher and research participants. At the core of narrative research, these dimensions share the understanding about the nature of social reality and individual persons' relationships with it as well as about the means of obtaining information about reality. Hänninen (2004), for her part, has introduced the model of narrative circulation that pulls together concepts and methodology of narrative research. She distinguishes three aspects of narratives: the told narrative, the inner narrative, and the lived narrative. In the model of narrative circulation, these various forms of narrative are viewed in relation to each other and to the social-cultural reality in which the person lives.

In this article, our purpose is to describe the core and nature of narrative research by leaning on Heikkinen's (2002b; Heikkinen, Huttunen, Syrjälä, \& Pesonen, 2012) categorization of the dimensions of the narrative research approach. The dimensions of the narrative research approach analyzed in this article were (1) the narrative approach in the meta-theoretical basis of the research; (2) the narrative approach in data collection; (3) the narrative approach in data analyses; (4) the narrative approach in the reliability evaluation of the research. The study used as an example in this article focused on the high-achieving Finnish upper secondary education graduates' (N=14) school paths (Salmela, 2016). To become graduates, students have to pass the general upper secondary education studies and the examination. Every year, about 30,000 students graduate from general upper secondary education, and 56-104 of them (0.19-0.35\%) score a laudatur in six or more subjects yearly (Matriculation Examination Board, 2012, 2015). In this study, the concept of a high-achieving graduate refers to a student who has gotten at least six laudatur grades from the matriculation examination when graduating.

The study employed the narrative approach in these four dimensions. The research approach was narrative because the purpose of the study was to describe the school paths according to the graduates' own narratives. The method was chosen because it allowed the research participants to share and describe their experiences, thoughts, and feelings about their paths. The research data were collected in the form of written narratives and interviews in 2012-2013. In this article, we describe and analyze the tasks included in the methodological approach in this study. The purpose is to create an overall picture of the possibilities of using the narrative approach and how it can be applied in various areas and phases of research. 


\section{The Narrative Approach in the Meta-Theoretical Basis of the Research}

The narrative research approach leans on the constructivist paradigm. The fundamental assumption is that people construct knowledge and their identities through narratives and within the interaction between themselves and their environment (Bruner, 1990; Heikkinen, 2002b; Polkinghorne, 1995; Spector-Mersel, 2010). The person's lived and current experiences and values, the audience of the narrative, and the time and place together have an impact on what kinds of narratives the person tells about the world and himself or herself. From this perspective, told narratives are multivoiced (Bruner, 1986; Heikkinen, 2002b; Moen, 2006).

Likewise, in the example study of this article, knowledge was constructed in a hermeneutical spiral (Bruner, 1991; Heikkinen, 2002a). The graduates who participated in the research structured the meanings they had given to their previous experiences and events when they described them to the researcher. They did not just recount the events and experiences but described them from their current perspective. Therefore, the events and their descriptions were not identical, but the relationship between them resembled a complicated interpretation process. On the other hand, the told narrative influenced them and their experiences of their lives, themselves, and their school paths. Thus, narratives and experiences lead the narrative forward in a spiral-like process (Heikkinen, 2002b).

Information produced in the example study was also constructed in this kind of a spiral process. The research began by leaning on previous positive psychological studies when viewing the high-achieving graduates' narratives. A new narrative of their study paths was constructed from the viewpoints of core positive psychological concepts, such as resources, strengths, and strength-based teaching. The researcher traveled between the graduates' narratives and previous research interpreting and re-interpreting the core items in the narratives and constructing new meanings for events included in the narratives. Thus, the narrative that was created by the researcher was not a direct copy or description of the graduates' narratives. Instead, it was an imperfect and partial reconstruction that was produced and written from the positive psychological framework through conscious and unconscious choices (Bruner, 1991; Elbaz-Luwisch, 2005; Pinnegar \& Daynes, 2007; Spector-Mersel, 2010).

Indeed, the conceptions of the nature of knowledge and reality and of the position of the researcher and research participants distinguished the example study from the positivist paradigm (Spector-Mersel, 2010). Namely, from the positivist perspective, the graduates would have been considered informants whose narratives described an objective, shared reality (Moen, 2006). Then, the researcher's task would have been to analyze their narratives objectively and consider the narratives as resources based on which the researcher's objective would have been to create laws that predict the phenomenon under investigation (Elliott, 2005; Spector-Mersel, 2010; Squire et al., 2014). However, the example study was situated within the narrative paradigm, meaning that the graduates were seen as research partners (Sarivaara, Uusiautti, \& Määttä, 2013). Their narratives were considered multi-faceted and -layered research themes (narrative as theme), which were analyzed in the light of certain values, stereotypes, images, and aptitudes (Elliott, 2005; Moen, 2006). Thus, the study revealed only a partial version of reality and was no more right or wrong than the graduates' or other researchers' possible interpretations of the research data (Pinnegar \& Daynes, 2007).

\section{The Narrative Approach in Data Collection}

In the example study, the data consisted of written $(\mathrm{N}=14)$ and oral $(\mathrm{N}=7)$ narratives. When designing the writing assignment, it was important to pay attention to the phrasing, as the goal was, on one hand, to let the graduates decide what they want to include in and exclude from their narratives and, on the other hand, to instruct them to write about the core theme of the research from a certain perspective, which was their strengths and resources (Uusiautti, 2008). The writing assignment presented the desire that the graduates would write free-form about their study paths from elementary school all the way to their graduation from upper secondary education by thinking back all those events and people, experiences, thoughts, and feelings that had been 
important and meaningful to them. To spur their writing, they were given suggestions about themes they could write about if they felt that they needed guidance or ideas. For example, one of the suggestions was to write about the hopes and expectations they had had at school and about their top moments throughout the course of their study. It was emphasized that they could freely choose their own way of writing and decide the sequence of events or issues in their narratives.

In the second phase of the research, the researcher sent an interview request to all graduates who had written their narratives. The researcher wanted to give the graduates an opportunity to express themselves in ways they found the most suitable: for some, writing was a more familiar way of expressing themselves, but for others, the opportunity to describe their school paths orally was more pleasing. Furthermore, it was possible to specify sections in the written stories during the interviews and discuss further the themes included in the written narratives. Half of the graduates $(\mathrm{N}=7)$ who had written their narratives participated in the personal interview. The interview started with an open question: "Tell me how you became a graduate." As the interview went on, the researcher presented more "tell me" -type questions, encouraging the interviewees to create narratives. "Tell me about the top moments at school," or "Tell me more about those lessons and teachers you liked at school." The purpose was to let them freely describe events and experiences important in the light of the research theme (Bates, 2004; Connelly \& Clandinin, 1990; Elliott, 2005; Spector-Mersel, 2010). When necessary, the interviewer asked additional questions and referred to the graduates' narratives by noting "In your written narrative, you said that... Could you tell me more about it?" By these kinds of open questions, the purpose was to empower the graduates to produce and tell their narratives and to decide what and how they would share about their study paths (Elliott, 2005; Hänninen, 2004).

It is reasonable to question to what extent the data in the example study were narrative in form. Their narratives resembled narratives that have the features of a traditional story: they had the beginning, center, and end, and a chronologically proceeding, consistent plot (Polkinghorne, 1995; also see Squire et al., 2014). On the other hand, a narrative could include the so-called small stories (as expressed by Bamberg). These small stories could emerge within the interaction between the researcher and the research participant and described quite mundane events and issues without including all the features of a traditional narrative (Bamberg, 2006, 2012; Bamberg \& Georgakopoulou, 2008). Both these narrative types are certain kinds of presentations of their narrators as well as the interaction between the researcher and the research participants. Furthermore, they reveal something about the social, cultural, and moral world (Squire et al., 2014), which means that the narratives illustrate the situations of the narration event in which the narrator analyzes the event, creates meanings for it and his or her related emotions, and expresses his or her identity and way of understanding his or her and others' action (Bruner, 1986; Holstein \& Gubrium, 2012; Hänninen, 2004; Polkinghorne, 1995).

According to Polkinghorne (1995), any data based on narration when a certain coherence and plot are not required can be considered narrative data (also see Bamberg, 2006; Squire et al., 2014). In the example study, the interview method resembled the episodic method (Bates, 2004). According to Bates (2004), an episodic interview is one of the narrative interview techniques acquiring descriptions of episodes that take place in the interviewees' daily lives. It accepts the idea that narratives constructing reality are not usually coherent but can consist of many short, limited narratives or episodes (Bates, 2004). Similarly, Andrews (2010; also see Squire et al., 2014) questions whether it is possible to expect that the narrative data have a consistent form and structure because life itself is a state of eternal continuity. People only structure their lived lives afterwards into a sequence of events because it makes their chaotic lives seem more controllable. In this sense, a narrative is retrospective meaning-making - the construction and analysis of past experiences (Bruner, 1986; Chase, 2008; Polkinghorne, 1995).

Thus, the data in the study could be considered narrative by nature. The narratives not only expounded, but they also constructed the events into a chronological narrative in which events were explained in light of the certain historical and social context (Squire et al., 2014). Thus, the coherence of the narratives in the example study did not refer to the coherent or logical structure of a narrative or its plot but to the fact that graduates were 
How to implement the narrative approach in different phases of a positive psychological research?

constructing their narratives in interaction with the researcher and their surrounding environment (Moen, 2006; Squire et al., 2014).

\title{
4. The Narrative Approach in Data Analyses
}

In the example study of this article, various narrative analysis methods were applied to meet the research tasks (Holstein \& Gubrium, 2012; Riessman, 2008). Lincoln and Denzin (1994) discussed bricoleur referring to the creative use of various analysis methods. The analysis process was a combination of Polkinhorne's (1995) analysis of narratives, Lieblich, Tuval-Maschiach, and Zilber's (1998) category-content analysis, and McAdams' (2012) context of discovery when aiming at categorizing and grouping items in the data into new themes. The objective was to find common features, themes, and regularities that would provide answers to research questions. These analyses focused on the contents of the narratives-what did the graduates tell-instead of analyzing how the graduates constructed their narratives (Chase, 2008; Holstein \& Gubrium, 2012). The following two data excerpts describes the kinds of items that were categorized into, for example, a theme describing the graduates' enthusiasm, curiosity, and inner motivation as strengths typifying their passion for learning:

\begin{abstract}
I remember as a child waiting to get to school. My mom taught me to read and write when I was three-four, because I had been really interested in learning those skills and been constantly dragging books to her that I wanted to read by myself. The example in question shows that I was already enthusiastic to learn when I was little and I have also worked in a very goal-oriented manner to learn. (Student9, written narrative, July 2012)
\end{abstract}

The analysis process in the example process also followed differences analysis (Alasuutari, 1995, 1996) to determine what kind of differences the data included when it came to the graduates' descriptions of the best teachers and their action. The following data excerpt describes how graduates created meaning about their teachers and their actions by contrasting them to teachers who act in the opposite manner:

They [teachers] were really demanding but really fair too. And you could see that they were really interested in their subject, clearly sought information [about the subject], and tried to include their own thing in it. I mean, it was not just that textbook studying, but other things too. (Student2, individual interview, July 2013)

The example study leaned on positive theoretical study that directed analyses to some extent. However, the purpose of the analysis was not to strengthen the pre-determined theoretical categories or test the theory (McAdams, 2012), but the theoretical basis was seen to function as the means to do data-based analysis. The analysis proceeded from down to top so that it started from the data and proceeded, step by step, toward thematic abstractions (McAdams, 2012).

In addition to content categorizations, the analysis followed Polkinghorne's (1995) narrative analysis that combined the graduates' narratives into new narratives, as the analyses thus far had focused on common themes and similarities in the data. However, in the narrative approach, every graduate's narrative must be regarded as individual and unique, despite the similarities within the data (Bruner, 1986, 1990; Heikkinen, 2001). Each narrative was read again to ascertain its difference from the others. Each narrative was analyzed by asking which themes were more present and which ones less present in their narratives with a four-scale matrix (see Eskola, 2010). This analysis showed that the narratives differed from each other by having certain themes more strongly present than others, and thus it was possible to combine those narratives that had similar differences as their own groups (also see Ylijoki, 1998). This grouping led to four slightly different descriptions of the graduates' school paths: an independent study path, a study path as a pursuit of perfection, with an emphasis on human relationships, and as work. Thus, the analysis is also a synthesis of the data, not merely the separation into parts and categories (Polkinghorne, 1995). 
It is relevant to ask how narrative the analysis process was because in the example study, the narrative character or plot was not studied (Riessman, 2008; Squire et al., 2014). One way of divide analysis methods is to distinguish whether the analysis focused on the content or on the form of the narrative (Chase, 2008; Holstein \& Gubrium, 2012; Riessman, 2008). Another way of viewing the analysis is to consider whether the analysis approached the narratives as entities or as parts (Lieblich et al., 1998). Lieblich et al. (1998) suggested that analysis can be viewed in two dimensions: content vs. form and holistic vs. categorical (also see Riessman, 2008). Based on these definitions, the analysis in the example study resembled categorical content analysis when the purpose was to analyze what they described in their narratives (Lieblich et al., 1998). Polkinghorne (1995) referred to the analysis of narratives, and likewise, McAdams' (2012) context of discovery categorizes various themes and qualitative categories from the narratives and creates new theoretical aspects.

As the example study showed, it is not easy to distinguish the different narrative analysis methods from each other. Instead, it is often more reasonable to mold the methods to serve the research purposes the best within the constant dialogue between the theoretical framework, research questions, data, and the researcher. By applying various analysis methods, it was possible to describe the data in interesting ways and highlight different sides of it. For example, the narratives of study paths summarized the core themes in the data by simultaneously bringing out the multiple voices of participants in the data.

\section{The Narrative Approach in the Reliability Evaluation of the Research}

As the narrative approach leans on a constructivist viewpoint (see, e.g., Bruner, 1990; Polkinghorne, 1995), knowledge is not considered an objective description of the world and independent from individuals, but as constructed by people and communities (Heikkinen, Huttunen, Kakkori, \& Tynjälä, 2006). Therefore, the concepts of validity and reliability that are based on realism could not be used in the evaluation of reliability in the study (Heikkinen, Huttunen, Syrjälä, \& Pesonen, 2012). Instead, in the example study, reliability evaluations were made using Heikkinen et al.'s (2012) five principles of validation: reflexivity, historical continuity, dialectics, evocativeness, and workability and ethics.

The principle of reflexivity means that the researcher must express the ontological and epistemological assumptions in the study (Heikkinen et al., 2012). In the example study, the meta-theoretical assumptions could be seen in the researcher's way of analyzing and interpreting the graduates' narratives. This meant, for example, that as with the oral narratives, the written narratives were also regarded as socially negotiated and constructed, and dialogical (Hall, Robinson \& Crawford, 2000; Squire et al., 2014). When writing their narratives, the graduates had to pay attention to the writing request, their own writing style and phrasing, and what the researcher might already know and would like to know about them (Hall et al., 2000; also see Uitto, 2011). The researcher's role similarly influenced the written narratives like it influenced the interviews (see also Goffman, 1959).

The narratives were created in a certain environment and filled with choices and interpretations of reality. Obviously, the narratives would have been different if shared between friends than what they were when shared with the researcher. Therefore, the research data consisted of revealed, shared narratives (elicited stories) that were specifically created for the researcher and the research, not during a spontaneous discussion or in a natural environment (Bamberg, 2006; Riessman, 2008; Spector-Mersel, 2010). Thus, the data were merely a construction made together by the graduates and the researcher (Squire et al., 2014). Reflexivity referred to the dialogue during which the narratives were deconstructed and reconstructed so that the new narrative created in the research would not lose its connection with the original narratives (Squire et al., 2014). According to Blumenfeld-Jones (1995), narrative research is being in between which necessitates that the relationship between the researcher and research participant, and the narrative and its context is acknowledged. Furthermore, reflexivity means transparency (Heikkinen et al., 2012). In the example study, the research process was described in detail in the report and research articles. When presenting the findings, excerpts from the data were included to show the validity of the interpretations and the connection between interpretations and empirical evidence 
(Heikkinen et al., 2012).

The principle of reflexivity is tied with the principle of historical continuity. The sequence of events was intentionally plotted so that the research report would form a logical entity. The purpose was to give readers an understanding about the events and why the narratives were led in certain directions in the research (Heikkinen et al., 2012). In addition, general upper secondary education was viewed as a part of the Finnish education system, thus positioning the research in the current societal context.

Studies that follow the principle of dialectics try to transmit the polyphony of various voices and thoughts in which social reality is seen as multi-voiced speech (Heikkinen et al., 2012). In the example study, the graduates' study paths were viewed from the perspective of positive psychological concepts by employing various narrative analyzing methods to highlight the different voices and thoughts in the data. The principle of dialectics includes the idea that the researcher should discuss the interpretations with the research participants (Heikkinen et al., 2012; see Harré \& Secord, 1972; Hatch \& Wisniewski, 1995; Moen, 2006). This is not always possible in research for various reasons. In this study, the graduates were not contacted for this purpose. However, there are other ways of enhancing the principle, and here, the interpretations were discussed and evaluated with other researchers. Likewise, the research articles introducing the findings went through the review processes, which for their part, strengthen the dialectical dimension.

Furthermore, some researchers say that having the research participants evaluate the researcher's interpretations about the data can be problematic because we are not always aware of or honest about the reasons behind our actions (Phillips, 1997). Phillips (1997) argued that sometimes an outsider-researcher can report a certain event more truthfully than the research participants themselves. According to Josselson (2007), research is always the researcher's interpretation, and therefore, the purpose is not even to tell about the research participants as such but merely about the meanings the researcher constructs. Therefore, the principle of dialectics does not mean that absolute truths should be sought and presented (Heikkinen et al., 2012) but it allows several reasoned interpretations (Ylijoki, 1998) and multiple voices (Moen, 2006).

The principle of evocativeness refers to the way the research arouses images, memories, and feelings about the research theme (Heikkinen et al., 2012). By citing Bruner (1986), Heikkinen (2002b) emphasized verisimilitude instead of truth. As mentioned, the narrative truth is not absolute (Squire et al., 2014), but verisimilitude is based on the way the reader can live the story and experience the reality presented in the narrative like a simulation (Bruner, 1986). When a narrative is vivid, it does not matter if the events have happened in an actual place (Squire et al., 2014). Instead it is important that the world described in the narrative becomes understandable and plausible to readers so that they start to understand the main characters' lives and choices in their specific contexts in the narrative (Heikkinen, 2001; 2002b). In the example study, the purpose was to describe the graduates' school paths so that readers would be able to agree with the interpretations of the resources, strengths, and other events in the narrative, even though they had no experience of such school paths themselves.

The principle of evocativeness is close to the concepts of rhetorical criteria (Ylijoki, 1998) and resonance (Clandinin \& Connelly, 2000; also see Squire et al., 2014) when referring to the rhetoric strength of the research. Therefore, the reliability of the example study appeared not only as a proper, fluent description, but also as a resonance with the audience's experiences (Blumenfeld-Jones, 1995). From the narrative perspective, a good story has some similarity but also some otherness, difference. The similarity leads the reader inside the narrative, but the difference expands the experience (Heikkinen, 2001). One may question what the difference that guaranteed the expanded experience was in the example study. The question is closely connected with the principles of workability and ethics (Heikkinen et al., 2012) that are based on the historical roots of narrative action research: pragmatism. The workability of the study was highlighted by explaining how the findings could be used in the Finnish schools and in teaching.

The principle of workability gets deeper when analyzing the ethics of the study (Heikkinen et al., 2012). In 
Salmela, M., \& Uusiautti, S.

the example study, the anonymity of the research participants had to be secured, but this was a difficult task due to the low number of extraordinarily high-achieving graduates in Finland. In addition, their narratives included other people who did not necessarily want to participate in the study. They had probably experienced the events in the narratives in their own ways that could differ from the ones described by the graduates (Josselson, 2007).

However, the principle of ethics covers much more than just anonymity protection. Josselson (2007) refers to an ethical attitude and Noddings (2005) to the ethics of caring when two people encounter one another. Each graduate had their own narratives that should be analyzed sensitively and with understanding. The researcher's voice is, however, present in the solutions and decisions during the research and in the final research report. For example, the researcher decided which and what kinds of data excerpts were included in the report, who (of the research participants) was referred to the most, and how the narratives were interpreted. Elbaz-Luwisch (2005) talks about the researcher's attention, referring to the fact that the researcher more easily hears some participants' voices than others. In the dialogue between the researcher and the graduates, the narratives were detached from their original context, and they were reconstructed within the new interpretation framework (Moen, 2006). Thus, the researcher could exclude voices that were not necessarily important from the viewpoint of the search theme but could have been of primary importance to the graduates. In addition, the selection of the theoretical framework was an ethical choice because it made certain concepts and objectives central to the research. This choice could mean that the narratives were used within such a framework that was opposed to the graduates' own ideas or did not feel suitable. The solutions and interpretations form the core of the ethical question of who owns the narrative of graduates' school paths eventually and with whose terms it was created (Syrjälä, Estola, Uitto, \& Kaunisto, 2006).

Heikkinen et al. (2012) specified that the five validation principles are general guidelines and that the purpose is not to evaluate the reliability of the research one criterion at a time. The example study and its reliability analysis become more than the sum of these criteria. Research was a constant hermeneutical and interpretative process that started from the selection of the research theme and continued throughout the entire research process. However, the hermeneutic process did not end with the research report, but the report presented new opportunities of interpretation (Moen, 2006; Ricouer, 1982).

\section{Discussion and Conclusion}

The narrative approach is chosen in research when the purpose is to understand a person's or group's identity development and construction (see, e.g., Heikkinen, 2001; Kotze, Coetzee, Elliker, \& Eberle, 2015; Tasker \& Delvoye, 2015) or to highlight viewpoints on coping, recovery, hope, or success (see, e.g., Bishop \& Willis, 2014; Mansfield, Mclean, \& Lilgendahl, 2010; Savukoski, Määttä, \& Uusiautti, 2012; Uusiautti, 2008). In addition, narrative research can focus on negative life changes or experiences of some special or minority group (see, e.g., Hershberg \& Lykes, 2013; Hiller, Linstroth, \& Vela 2009; Hänninen, 1999; Prins, 2008). The purpose of this article was to analyze the nature of narrative research and its core by reflecting them in light of the methodological choices in the example study (Salmela, 2016).

As mentioned in the Introduction, the high-achieving graduates represent a very marginal group among Finnish upper secondary education students. This form of education is also considered quite a demanding and time-consuming one, and according to wide surveys, Finnish students suffer from stress and fatigue as well as time pressure and workload (see, e.g., Korppas, 2007; Laitinen, 2012; Tuominen-Soini \& Salmela-Aro, 2014). In the example study, we tried to provide new, positive viewpoints on this image of pressures and demands by highlighting resources, strengths, and strength-based teaching. By introducing new kinds of narratives that describe students' strengths and successes, the study directed attention to a less-studied group of students, emphasized flourishing at school, and gave examples of how to deal positively with the stressful general upper secondary education.

This article also described how the meta-theoretical understanding can be combined with methods to study 
How to implement the narrative approach in different phases of a positive psychological research?

reality within the narrative research approach. Spector-Mersel (2010, p. 220) points out that the narrative paradigm is

a full-fledged research world view that closely binds up the "hows" of investigation (methodology) to the "whats" and "whys" (ontology and epistemology).

In the example study, the primary goal was not only to gather narrative data, but also to let the data collection situation mold the criterion of narrative data in that particular study. Therefore, the idea was to respect the data collection situations by not focusing on how the written and oral narratives would fulfill the features of a traditional narrative (also see Bamberg, 2012; Bamberg \& Georgakopoulou, 2008; Squire et al., 2014). In addition, as Riessman (2008) suggests, narrative research should not focus too much on predetermined categories and, therefore, analysis can also concentrate on themes that are developed during the creation of the narrative-during writing and interviewing in the example study. This can be justified with the conception of the forms of narrative knowledge. On one hand, narrative cognition means creating a thematically and logically proceeding narrative about singular events (Bruner, 1986), but on the other hand, narrative analysis methods cannot be limited to serve just one kind of a data type, but merely, our interpretation is that methods should be applied to each data type in a way that is reasonable in light of the research questions. This viewpoint is supported by the relational constructionist account of narrative (Gergen \& Gergen, 2011) based on which we can state that narrative research and its methodological solutions are always social.

The meta-theoretical basis of the narrative research approach also influenced the way in which truth and reliability were understood in the example study. Both the graduates' narratives and the researcher's report can be seen as fictional statements that can be viewed in light of the concepts of facts, facilities, and fiction (Denzin, 1989; Moen, 2006). Facts refer to the actual events that took place during the graduates' study paths, whereas facilities describe how the actual events were lived and experiences in the interaction between the graduates and the researcher. Therefore, fiction means the narrative that covered the actual events in the study paths and the lived and experienced facts. Fiction reflects facts and facilities, and therefore, the truth and reliability of the example study were not objective, static, and eternal descriptions of the reality but constantly changing and interpretative.

The four roles that the narrative approach had in the example study and described in this article can appear purely only in narrative research. However, it also became evident that each role has its own meaning in the dialogue that the study includes between the research questions, theoretical framework, and methodological choices, as well as between the researcher and the research participants. The example study is just one example of how these roles can appear in a study and what kinds of decisions a researcher might have to make when conducting narrative research.

More importantly, it is also necessary to understand that this four-dimensional illustration is not a comprehensive answer to a question of what and how narrative research is—or how it should be-done. Instead, the roles can be challenged, and better interpretations of applying narrative research and its nature can be made (Gergen \& Gergen, 2011). However, for a researcher starting a narrative study, a description of how narrative research appears in different phases of research can be helpful and provide inspiration and guidelines for how research could be done. In this sense, the article at hand provided a narrative of a narrative study, presenting an interpretation of the usability of the narrative approach in different phases of research.

Acknowledgments - This research was funded by the Finnish Cultural Foundation, Lapland Regional fund.

\section{References:}

Alasuutari, P. (1995). Researching culture: Qualitative method and cultural studies. London: Sage.

Alasuutari, P. (1996). Theorizing in qualitative research: A cultural studies perspective. Qualitative Inquiry, 2(4), 
Salmela, M., \& Uusiautti, S.

371-384. https://doi.org/10.1177/107780049600200401

Andrews, M. (2010). Beyond narrative. The shape of traumatic testimony. In Matti Hyvärinen, Lars C. Hydén, Marja Saarenheimo, \& Maria Tamboukou (Eds.), Beyond narrative coherence (pp. 147-166).

Philadelphia: John Benjamins. https://doi.org/10.1075/sin.11.09and

Bamberg, M. (2006). Biographic-narrative research, Quo Vadis? A critical review of 'Big Stories' from the perspective of 'Small Stories'. In Kate Milnes, Christine Horrocks, Nancy Kelly, Brian Roberts, \& David Robinson (Eds.), Narrative, memory and knowledge: Representations, aesthetics and contexts (pp. 63-79). Huddersfield: University of Huddersfield Press.

Bamberg, M. (2012). Why narrative? Narrative Inquiry, 22(1), 202-210. https://doi.org/10.1075/ni.22.1.16bam

Bamberg, M., \& Georgakopoulou, A. (2008). Small stories as a new perspective in narrative and identity analysis. Text \& Talk, 28(3), 377-396. https://doi.org/10.1515/TEXT.2008.018

Bates, J. A. (2004). Use of narrative interviewing in everyday information behavior research. Library \& Information Science Research, 26(1), 15-28. https://doi.org/10.1016/j.lisr.2003.11.003

Bishop, E. C., \& Willis, K. F. (2014). "Hope is that fiery feeling": Using poetry as data to explore the meanings of hope for young people. Forum Qualitative Sozialforschung / Forum: Qualitative Social Research, 15(1), Art. 9, http://www.qualitative-research.net/index.php/fqs/article/view/2013/3632

Blumenfeld-Jones, D. (1995). Fidelity as a criterion for practicing and evaluating narrative inquiry. In J. Amos Hatch \& Richard Wisniewski (Eds.), Life history and narrative (pp. 25-35). London: Falmer. https://doi.org/10.1080/0951839950080104

Bruner, J. (1986). Actual minds, possible worlds. Cambridge, MA: Harvard University Press.

Bruner, J. (1990). Acts of meaning. Cambridge: Cambridge University Press.

Bruner, J. (1991). Narrative construction of reality. Critical Inquiry, 18(1), 1-21. https://doi.org/10.1086/448619

Carter, K. (1993). The place of story in the study of teaching and teacher education. Educational Research, 22(1), 5-12, 18. https://doi.org/10.3102/0013189x022001005

Chase, Susan E. (2008). Narrative inquiry: Multiple lenses, approaches, voices. In Norman K. Denzin \& Yvonna S. Lincoln (Eds.), Collecting and interpreting qualitative materials (pp. 57-94). London: Sage.

Clandinin, D. J., \& Connelly, F. M. (2000). Narrative inquiry. Experience and story in qualitative research. San Francisco, CA: Jossey-Bass.

Clandinin, D. J., \& Rosiek, J. (2007). Mapping a landscape of narrative inquiry. Borderland spaces and tensions. In D. Jean Clandinin (Ed.), Handbook of narrative inquiry (pp. 35-75). London: Sage. https://doi.org/10.4135/9781452226552

Connelly, F. M. \& Clandinin, D. J. (1990). Stories of experience and narrative inquiry. Educational Researcher, 19(5), 2-14. https://doi.org/10.3102/0013189X019005002

Denzin, N. K. (1989). Interpretive biography. Newbury Park: Sage. https://doi.org/10.4135/9781412984584 Elbaz-Luwisch, F. (2005). Teachers' voices: Storytelling and possibility. Greenwich: Information Age Publishing. Elliott, J. (2005). Using narrative in social research. Qualitative and quantitative approaches. London: Sage. https://doi.org/10.4135/9780857020246

Eskola, J. (2010). Laadullisen tutkimuksen juhannustaiat. Laadullisen aineiston analyysi vaihe vaiheelta [The magic of qualitative research. Qualitative data analysis phase by phase]. In Juhani Aaltola \& Raine Valli (Eds.), Ikkunoita tutkimusmetodeihin II. Näkökulmia aloittelevalle tutkijalle tutkimuksen teoreettisiin lähtökohtiin ja analyysimenetelmiin [Perspectives on research methods II. Viewpoints of theoretical principles and analyzing methods in research to beginning researchers] (pp. 179-203). Juva: PS-kustannus.

Gergen, K. J. \& Gergen, M. M. (2011). Narrative tensions. Perilous and productive. Narrative Inquiry, 21(2), 374-381. https://doi.org/10.1075/ni.21.2.17ger

Goffman, E. (1959). The presentation of self in everyday life. New York, NY: Doubleday Anchor Books.

Hall, N., Robinson, A., \& Crawford, L. (2000). Young children's explorations of letter writing. In David Barton \& Nigel Hall (Eds.), Letter writing as a social practice. Studies in written language and literacy (pp. 131-149). Philadelphia: John Benjamins. https://doi.org/10.1075/swll.9.08hal

Harré, R., \& Secord, P. F. (1972). The explanation of social behaviour. Oxford: Basil Blackwell. 
How to implement the narrative approach in different phases of a positive psychological research?

Hatch, J. A., \& Wisniewski, R. (1995). Life history and narrative: Questions, issues, and exemplary works. In J. Amos Hatch \& Richard Wisniewski (Eds.), Life history and narrative (pp. 113-135). London: Falmer. https://doi.org/10.1080/0951839950080102

Heikkinen, H. L. T. (2001). Toimintatutkimus, tarinat ja opettajaksi tulemisen taito. Narratiivisen identiteettityön kehittämisen opettajankoulutuksessa toimintatutkimuksen avulla [Action research, narratives, and the ability to become a teacher. Developing narrative identity work in teacher training through action research]. Jyväskylä studies in education, psychology and social research 175. Jyväskylä: University of Jyväskylä.

Heikkinen, H. L. T. (2002a.) Narratiivisuus - ei yksi vaan monta tarinaa [The narrative approach - not just one but many narratives]. In Hannu L. T. Heikkinen \& Leena Syrjälä (Eds.), Minussa elää monta tarinaa. Kirjoituksia opettajuudesta [Many narratives live inside me. Writings about teacherhood] (pp. 184-197). Helsinki: Kansanvalistusseura.

Heikkinen, H. L. T. (2002b). Whatever is narrative research? In Rauno Huttunen, Hannu L. T. Heikkinen \& Leena Syrjälä (Eds.), Narrative research. Voices of teachers and philosophers (pp. 13-28). Jyväskylä: SoPhi.

Heikkinen, H. L. T., Huttunen, R., Kakkori, L., \& Tynjälä, P. (2006). Totuuden ongelma [The problem of truth]. In Hannu L. T. Heikkinen, Esa Rovio \& Leena Syrjälä (Eds.), Toiminnasta tietoon. Toimintatutkimuksen menetelmät ja lähestymistavat [From action to knowledge. Action research methods and approaches] (pp. 163-183). Helsinki: Kansanvalistusseura.

Heikkinen, H. L. T., Huttunen, R., Syrjälä, L., \& Pesonen, J. (2012). Action research and narrative inquiry: five principles for validation revisited. Educational Action Research, 20(1), 5-21. https://doi.org/10.1080/09650792.2012.647635

Hershberg, R. M., \& Lykes, M. B. (2013). Redefining family: Transnational girls narrate experiences of parental migration, detention, and deportation. Forum Qualitative Sozialforschung / Forum: Qualitative Social Research, 14(1), Art. 5, http://www.qualitative-research.net/index.php/fqs/article/view/1770/3476

Hiller, P. T., Linstroth, J. P., \& Vela, P. A. (2009). "I am Maya, not Guatemalan, nor Hispanic"—the belongingness of Mayas in Southern Florida. Forum Qualitative Sozialforschung / Forum: Qualitative Social Research, 10(3), Art. 10, http://www.qualitative-research.net/index.php/fqs/article/view/1361/2853

Holstein, J. A., \& Gubrium, J. F. (2012). Varieties of narrative analysis. London: Sage. https://doi.org/10.4135/9781506335117

Hänninen, V. (1999). Sisäinen tarina, elämä ja muutos [Inner narrative, life, and change]. Acta Universitatis Tamperensis 696. Tampere: University of Tampere.

Hänninen, V. (2004). A model of narrative circulation. Narrative Inquiry, 14(1), 69-85. https://doi.org/10.1075/ni.14.1.04han

Josselson, R. (2007). The ethical attitude in narrative research. Principles and practicalities. In D. Jean Clandinin (Ed.), Handbook of narrative inquiry. Mapping a methodology (pp. 536-566). London: Sage. https://doi.org/10.4135/9781452226552.n21

Korppas, M. (2007). Opintojen kuormittavuus ja nuorten koulu-uupumus [The burden of studies and fatigue at school in the youth]. In Kirsi Klemelä, Erkki Olkinuora, Risto Rinne, \& Arja Virta (Eds.), Lukio nuorten opiskelutienä. Turkulainen lukio opiskelijoiden, vanhempien ja opettajien silmin 2000-luvun alussa [General upper secondary education as the study path of the youth] (pp. 153-179). Turku: University of Turku.

Kotze, P. C., Coetzee, J. K., Elliker, F., \& Eberle, T. S. (2015). Strangers but for stories: The role of storytelling in the construction of contemporary white Afrikaans-speaking identity in Central South Africa. Forum Qualitative Sozialforschung / Forum: Qualitative Social Research, 16(1), Art. 20, http://www.qualitative-research.net/index.php/fqs/article/view/2133/3767

Laitinen, L. (2012). Onnelliset opintiellä? Lukiolaisten hyvinvointitutkimus 2012 [The happy on the study path? Survey of wellbeing among the general upper secondary education students 2012]. Helsinki: Suomen Lukiolaisten Liitto. 
Salmela, M., \& Uusiautti, S.

Lieblich, A., Tuval-Mashiach, R., \& Zilber, T. (1998). Narrative research: Reading, analysis, and interpretation. London: Sage. https://doi.org/10.4135/9781412985253

Lincoln, Yvonne \& Denzin, Norman (1994). The fifth moment. In Norman Denzin \& Yvonne Lincoln (Eds.), Handbook of qualitative research (pp. 575-586). London: Sage.

Mansfield, C. D., McLean, K. C., \& Lilgendahl, J. P. (2010). Narrating traumas and transgressions. Narrative Inquiry, 20(2), 246-273. https://doi.org/10.1075/ni.20.2.02man

Matriculation Examination Board. (2012). Ylioppilastutkinto 2011. Tilastoja ylioppilastutkinnosta [Matriculation Examination 2011. Information about Matriculation Examination]. Helsinki: Matriculation Examination Board.

Matriculation Examination Board. (2015). Laudaturien lukumäärä [The number of laudatur grades]. Helsinki: Matriculation Examination Board. https://www.ylioppilastutkinto.fi/images/sivuston_tiedostot/stat/FS2014A2012T4003.pdf

McAdams, D. P. (2012). Exploring psychological themes through life-narrative accounts. In James A. Holstein \& Jaber F. Gubrium (Eds.), Varieties of narrative analysis (pp. 15-32). London: Sage. https://doi.org/10.4135/9781506335117.n2

Moen, T. (2006). Reflections on the narrative research approach. International Journal of Qualitative Methods, 5(4), 56-69. https://doi.org/10.1177/160940690600500405

Noddings, N. (2005). The challenge to care in schools. An alternative approach to education. New York, NY: Teachers College Press.

Phillips, D. C. (1997). Telling the truth about stories. Teaching and Teacher Education, 13(1), 101-109. https://doi.org/10.1016/S0742-051X(96)00030-3

Pinnegar, S., \& Daynes J. G. (2007). Locating narrative inquiry historically. In D. Jean Clandinin (Ed.), Handbook of narrative inquiry. Mapping a methodology (pp. 3-34). London: Sage. https://doi.org/10.4135/9781452226552.n1

Polkinghorne, D. E. (1995). Narrative configuration in qualitative analysis. In J. Amos Hatch \& Richard Wisniewski (Eds.), Life history and narrative (pp. 5-23). London: Falmer. https://doi.org/10.1080/0951839950080103

Prins, E. H. (2008). Maturing out and the dynamics of the biographical trajectories of hard drug addicts. Forum: Qualitative Social Research, 9(1), Art. 30, http://www.qualitative-research.net/index.php/fqs/article/view/322/706

Ricouer, P. (1982). Hermeneutics and the human sciences: essays on language, action and interpretation. Cambridge: Cambridge University Press.

Riessman, C. K. (2008). Narrative methods for the human sciences. London: Sage.

Salmela, M. (2016). Tie ylioppilastutkinnon huippuarvosanoihin laudaturylioppilaiden kertomana [Paths to the highest scores in the Finnish Matriculation Examination as described by straight-A graduates]. Rovaniemi: University of Lapland.

Sarivaara, E., Uusiautti, S., \& Määttä, K. (2013). Critical Sámi research as the means of finding ways of seeing. International Journal of Social Science Research, 2(1), 1-18. https://doi.org/10.5296/ijssr.v2i1.4521

Savukoski, M., Määttä, K., \& Uusiautti, S. (2012). Back to life: How to use positive psychology to beat anorexia. International Research Studies in Psychology, 1(2), 39-51. https://doi.org/10.5861/ijrsp.2012.v1i2.38

Spector-Mersel, G. (2010). Narrative research. Time for a paradigm. Narrative Inquiry, 20(1), 204-224. https://doi.org/10.1075/ni.20.1.10spe

Squire, C., Davis, M., Esin, C., Andrews, M., Harrison, B., Hydén, L. C., \& Hydén, M. (2014). What is narrative research? London: Bloomsbury.

Syrjälä, L., Estola, E., Uitto, M., \& Kaunisto, S. L. (2006). Kertomuksen tutkijan eettisiä haasteita [Ethical challenges of narratives' researcher]. In Jaana Hallamaa, Veikko Launis, Salla Lötjönen, \& Irma Sorvali (Eds.), Etiikkaa ihmistieteille [Ethics to human sciences] (pp. 181-202). Helsinki: Finnish Literature Association.

Tasker, F., \& Delvoye, M. (2015). Moving out of the shadows: Accomplishing bisexual motherhood. Sex Roles, 73(3), 125-140. https://doi.org/10.1007/s11199-015-0503-z 
Tuominen-Soini, H., \& Salmela-Aro, K. (2014). Schoolwork engagement and burnout among Finnish high school students and young adults: Profiles, progressions, and educational outcomes. Developmental Psychology, 50(3), 649-662. https://doi.org/10.1037/a0033898

Uitto, M. (2011). Storied relationships: students recall their teachers. Acta Universitatis Ouluensis Scientiae rerum socialium 122. Oulu: University of Oulu.

Uusiautti, S. (2008). Tänään teen elämäni parhaan työn. Työmenestys Vuoden Työntekijöiden kertomana [Today, I'll work better than ever. Employees of the year describe their experiences of success at work]. Acta Universitatis Lapponiensis 138. Rovaniemi: University of Lapland.

Ylijoki, O. H. (1998). Akateemiset heimokulttuurit ja noviisien sosialisaatio [Academic tribe cultures and the socialization of novices]. Tampere: Vastapaino. 
Salmela, M., \& Uusiautti, S. 